Article

\title{
Business, Human Rights and Climate Due Diligence: Understanding the Responsibility of Banks
}

\author{
Chiara Macchi * (D) and Nadia Bernaz \\ Law Group, Wageningen University and Research, Hollandseweg 1, 6706 KN Wageningen, The Netherlands; \\ nadia.bernaz@wur.nl \\ * Correspondence: chiara.macchi@wur.nl
}

check for

updates

Citation: Macchi, C.; Bernaz, N. Business, Human Rights and Climate Due Diligence: Understanding the Responsibility of Banks. Sustainability 2021, 13, 8391. https://doi.org/ $10.3390 /$ su13158391

Academic Editors:

Olga Martin-Ortega, Valerie Nelson,

Renginee G. Pillay and

Fatimazahra Dehbi

Received: 2 June 2021

Accepted: 20 July 2021

Published: 27 July 2021

Publisher's Note: MDPI stays neutral with regard to jurisdictional claims in published maps and institutional affiliations.

Copyright: (C) 2021 by the authors. Licensee MDPI, Basel, Switzerland. This article is an open access article distributed under the terms and conditions of the Creative Commons Attribution (CC BY) license (https:// creativecommons.org/licenses/by/ $4.0 /)$.

\begin{abstract}
Under the 2011 UN Guiding Principles on Business and Human Rights (UNGPs), banks, like all businesses, have a responsibility to respect human rights and to carry out human rights due diligence. Although climate due diligence is not explicitly included in the UNGPs, tackling an enterprise's direct and indirect climate change impacts is arguably a dimension of the corporate responsibility to respect human rights and should form part of the human rights due diligence process. At present, it is unclear how such responsibility applies to banks, whose contribution to climate change is mostly indirect. This article addresses the research question: how should the law be interpreted to form a coherent climate due diligence standard for banks? To address it, the article first maps out the climate responsibility of banks under international soft law standards and assesses privately developed guidance. It then elucidates the emerging concept of climate due diligence, reading climate change responsibilities into the now well-established corporate responsibility to respect human rights as authoritatively elaborated in the UNGPs. Finally, it explains how such normative standard applies to banks and unpacks the key elements that a bank's climate due diligence process should include.
\end{abstract}

Keywords: climate change; human rights; due diligence; banks; UN Guiding Principles on Business and Human Rights

\section{Introduction}

\subsection{Background: Banks and Climate Change}

Banks are key actors in the necessary energy transition and can significantly contribute to achieving the Sustainable Development Goals and the Paris Agreement's objectives. COP21 recognised that it is crucial to make 'finance flows compatible with a pathway toward low greenhouse gas emissions and climate-resilient development' [1]. Banks are increasingly under pressure from civil society, central banks and regulators to address the climate change impacts of their own operations and business relationships. Yet, while legislative, voluntary and business-led initiatives are multiplying, what is currently missing is a conceptualization anchored in international law of the responsibilities of banks in relation to climate change and its human rights impacts. We propose exploring the issue based on the most authoritative corporate accountability instrument currently existing at the international level, namely the UN Guiding Principles on Business and Human Rights (UNGPs). We argue that the corporate responsibility to respect human rights under the UNGPs also requires corporations, including banks, to assess and address their direct and indirect contribution to climate change, one of the biggest human rights threats of our time.

We start from the recognition that, in light of the climate emergency the world is currently facing, climate and human rights issues are closely interlinked. In a report published in 2015, the UN Environmental Programme (UNEP) presents the human rights implications of climate change. They explain how the Fifth Assessment Report of the Intergovernmental Panel on Climate Change (IPCC) 'provides a detailed picture of how 
the observed and predicted climactic changes will adversely affect millions of people and the ecosystems, natural resources, and physical infrastructure upon which they depend' [2]. On the basis of the IPCC report, the UNEP report elucidates which human rights are impacted both by climate change [2] and by climate change adaptation and mitigation strategies [2]. For example, climate change, which leads to rising sea levels, affects the rights of coastal communities to housing, to an adequate standard of living, and to food, among others [2]. Given that all companies, under the UNGPs, bear a responsibility to respect human rights, and that climate change is a major global human rights threat, this paper argues that companies are expected to address their direct and indirect impacts on the climate by conducting appropriate climate due diligence.

We focus in particular on the crucial role and responsibilities of the financial sector, concentrating primarily on banks. As pointed out by Forbes, 'banks have been criticized for contributing to climate change by funding fossil fuel projects (with the 60 largest banks investing $\$ 3.8$ billion in fossil fuel projects from 2016 to 2020)' [3]. There is some evidence that 'improved awareness of climate change-related risks, and the anticipation of more stringent policies are probably pushing banks out of climate-sensitive sectors towards greener business' [4]. However, major difficulties persist for banks in identifying and addressing the precise extent of their impacts on the climate, especially when it comes to assessing 'Scope 3' carbon emissions, namely the indirect emissions that occur in their value chain [3]. Indeed, banks' contribution to climate change is mostly indirect, thus raising distinct challenges as to the exact contours of their responsibility. Upcoming regulatory developments, emerging climate change litigation, as well as shareholder activism and shifting market dynamics are making it more urgent than ever to clarify the perimeter of such responsibility. This paper addresses the question by relying on the normative architecture of the UNGPs. Of particular relevance to this article are the so-called 'Scope 3' emissions, namely all indirect emissions (not deriving from the generation of purchased energy) that occur in the value chain of a company, including those linked to its investments. While this paper focusses on banks for simplicity, many of its conclusions also apply to other actors in the financial sector, for instance sovereign wealth funds or other investors holding shares in companies that contribute to climate change.

\subsection{Normative Framework and Research Questions}

For the purpose of this article, the term responsibility is to be understood as the corporate responsibility to respect human rights as articulated in the UNGPs. Although the UNGPs are a soft law instrument, they nevertheless use core human rights and labour standards as standards of conduct (Guiding Principle 12) [5]. We argue that the corporate responsibility to respect must be interpreted in light of international human rights law even though the UNGPs do not create corporate human rights obligations under international law. Therefore, our normative framework encompasses the UNGPs as well as relevant human rights law. We chose the UNGPs because it is the most sophisticated and accepted standard of conduct for companies that is explicitly connected with human rights law. Other international instruments, such as the Sustainable Development Goals and the industry-led Principles for Responsible Investment, envisage a role for the private sector, including financial institutions, in addressing climate change. However, these instruments are not normative in nature and only marginally relate to human rights law. We therefore take the position that they are too context dependent and cannot serve as a basis for framing the solid form of climate due diligence that the current climate emergency is calling for. Further research could explore the relationship between the climate due diligence standard we propose in this article and existing other instruments, but here the focus is on understanding the climate dimension of the corporate responsibility to respect human rights as it applies to banks. This firmly anchors our article to the developing field of business and human rights, which we define as a field of study 'about how business may negatively impact human rights and the various ways in which such violations can be prevented and addressed, including how business can be held accountable' [6]. 
Previous legal research has looked into the human rights responsibility of similar actors under the UNGPs [7-9] and human rights law more generally [10,11]. We build on this research by adding the climate dimension and focusing on the responsibilities of banks. Most of our conclusions will also be applicable to institutional investors and, possibly, to other entities in the financial sector.

Our approach is both evaluative and prescriptive. First, we map out the climate responsibility of banks under international soft law standards and point to the gaps in those standards when it comes to climate change. In doing so we evaluate the quality of the existing legal framework and question its suitability. We then move on to a prescriptive question, which is the main research question this article seeks to address: how should the law be interpreted to form a coherent climate due diligence standard for banks?

\subsection{Methods and Data}

As customary in legal research, our data set includes primary sources such as legal texts and official documents from public and private actors. To map out the climate responsibility of banks, as defined in our normative framework articulated above, we have drawn primarily from the UNGPs and the OECD Guidelines for Multinational Enterprises. We have also included privately developed guidance such as the Thun Group's discussion paper and the Equator Principles. Although the latter are of a different nature, they nevertheless help understand how the sector itself looks at its own responsibility. Besides primary sources, we have also used academic and grey literature where relevant. Having described the legal context, we then interpret it in a teleological manner, focusing on the broader societal goals, in this case addressing the climate emergency that threatens humanity. This leads to explaining the emerging concept of climate due diligence, building on Macchi's work [12]. Having clarified the concept, we then examine what it means in practice for the banking sector.

\subsection{Structure}

To set the normative framework for our article, we first map out the climate responsibility of banks under international soft law standards and assess existing privately developed guidance such as the Thun Group's discussion paper and the Equator Principles (Section 2). Secondly, we elucidate the emerging concept of climate due diligence, reading climate change responsibilities into the now well-established corporate responsibility to respect human rights as authoritatively elaborated in the UNGPs (Section 3). Thirdly, we look at how such normative standard applies to banks and unpack the key elements that a bank's climate due diligence process should include (Section 4). Finally, we briefly conclude (Section 5).

\section{Articulating the Climate Responsibility of Banks}

This section presents the applicable instruments placing responsibilities on banks in the areas of human rights and climate. As shown below, the UNGPs, the key international instrument on business and human rights, focus on human rights and do not explicitly mention environmental or climate-related issues. Other instruments, falling under both the public and private regulation categories, only mention climate in passing. From a normative perspective, there is no equivalent to the UNGPs in the areas of environmental protection, let alone climate change. Hence this section explores how, if at all, climate-related issues are incorporated within relevant human rights documents, and more importantly how climate issues may be read into them in case they contain no explicit provision. Section 2.1 focusses on public instruments, namely the UNGPs and the OECD Guidelines on Multinational Enterprises. Section 2.2 focusses on the privately developed guidance applicable to the banking sector, namely the Thun Group's discussion paper and the Equator Principles. 


\subsection{International Instruments}

The two main international instruments on business and human rights are the UNGPs and the OECD Guidelines on Multinational Enterprises [13]. Neither of those sets strong standards on climate change, though the Guidelines fare marginally better than the UNGPs in this respect, because reducing emissions is at least mentioned in their text.

The UNGPs were endorsed by the UN Human Rights Council in 2011 and they constitute the most elaborate, universally applicable instrument on business and human rights. Under the UNGPs, all business enterprises, in all sectors, have a responsibility to respect human rights (Guiding Principle 14). In practice, this means that banks should

(a) Avoid causing or contributing to adverse human rights impacts through their own activities, and address such impacts when they occur;

(b) Seek to prevent or mitigate adverse human rights impacts that are directly linked to their operations, products or services by their business relationships, even if they have not contributed to those (Guiding Principle 13)

In a piece published in 2018, Van Ho and Alshaleel explored the application of the UNGPs to the mutual funds industry, and made important observations that are relevant for the present article. Mutual funds require 'a different approach to human rights than what has been employed in the context of [foreign direct investment] FDI, bank loans, or project financing.' [7]. Relatedly, they observed that the impact a mutual fund may have on human rights is usually indirect [7]. The UNGPs differentiate between impacts that a business may 'cause', 'contribute', or be 'linked to'. Each of those 'participation terms', as coined by Van Ho, calls for distinct strategies from the business in question [14]. In the case of the financial sector, companies often do not cause or contribute to the harm (direct impact) but rather are directly linked to it (indirect impact). In this article, we look beyond human rights as such and focus on climate change.

Under the UNGPs, in order to meet their responsibility to respect human rights, businesses should carry out a human rights due diligence process 'to identify, prevent, mitigate and account for how they address their impacts on human rights' (Guiding Principle 15). The UNGPs contain relatively detailed provisions on the corporate responsibility to respect human rights, as well as guidance on how to carry out human rights due diligence, but they do not mention climate as such. Interpreting the UNGPs without making the connection to climate change, however, raises questions about the very relevance of this instrument, considering that climate change is 'the defining crisis of our times' [15] and that 'many severe human rights impacts can be traced to climate change' [16], thus inevitably linking the two issues [17]. Moreover, the contribution of the private sector to climate change is undeniable, especially, but not limited to, the extractive sector [18].

To tackle this crisis, all actors of global governance must be involved as a moral imperative. Approaching corporate responsibility from a moral perspective, Høyer Toft convincingly argues that corporations have backward- and forward-looking duties in the area of climate change that go beyond the UNGPs' 'do no harm' approach [19]. As Section 3 explains, the climate change responsibilities of corporations also emerge from a coherent interpretation of the UNGPs in the light of relevant legal principles. The District Court of the Hague (Netherlands) clearly articulated this idea in its judgment in Milieudefensie et al. v Royal Dutch Shell PLC, issued in May 2021 [20]. Royal Dutch Shell, the court emphasized, is 'responsible for significant $\mathrm{CO}_{2}$ emissions, which exceed the emissions of many states and which contributes towards global warming and a dangerous climate change in the Netherlands and in the Wadden region (....) with serious and irreversible consequences and risks for the human rights of Dutch residents and the inhabitants of the Wadden region (...)' [20].

That environmental, climate and human rights issues are interconnected also is reflected in the French duty of vigilance law of 2017 [21], as well as the EU Parliament Proposal for a Directive on Corporate Due Diligence and Corporate Accountability [22].

The OECD Guidelines for Multinational Enterprises, revised in 2011, are another key instrument in the area of business and human rights. Unlike the UNGPs, which apply to 
all businesses regardless of size, type or sector, the Guidelines apply only to multinational enterprises operating in or from adhering countries, currently all 38 OECD countries and 12 non-OECD countries [23]. In practice the OECD Guidelines apply to the global activities of the largest companies based in the most important capital exporting countries of the Americas, Europe, as well as Japan and Australia. The scope of the Guidelines is therefore not universal but still quite wide.

Alongside a human rights chapter whose language is closely aligned with the UNGPs, the Guidelines include an environment chapter. The term climate change is not explicitly mentioned in that chapter or indeed in the Guidelines. However, it is reasonable to interpret the term 'environmental impact' used throughout the text, as encompassing climate-related impact. Although they are not interchangeable, environmental harm and climate change harm are closely related. Not all environmental impact is the result of climate change. For example, industrial pollution such as oil spills pollution is unrelated to climate change but leads to biodiversity loss, a clear environmental harm, as well as to negative human rights impacts. Climate change also often results in severe harm to the environment, an issue in itself, as well as in human rights harm. Therefore, in the absence of a specific reference to climate change in the current version of the Guidelines, it makes sense to track how the Guidelines articulate the responsibility of multinational enterprises with regard to the environment, so as to elucidate their climate responsibility as well.

The environment chapter does mention reducing greenhouse gas emissions, albeit using very weak language. Paragraph 6 states that enterprises should

'continually seek to improve corporate environmental performance, at the level of the enterprise and, where appropriate, of its supply chain, by encouraging such activities as (b) development and provision of products or services that (...) reduce greenhouse gas emissions (...); (c) promoting higher levels of awareness among customers of the environmental implications of using the products and services of the enterprise, including, by providing accurate information on their products (for example, on greenhouse gas emissions (...); and (d) exploring and assessing ways of improving the environmental performance of the enterprise over the longer term, for instance by developing strategies for emission reduction (...).'

The terms 'improving performance' and 'encouraging activities' do not convey the central importance of climate issues for the planet and vulnerable populations. With a more positive outlook, one can also consider encouraging multinational enterprises to reduce emissions a first step which may lead to a stronger text when the Guidelines are next revised. The Guidelines also include a recommendation, under their Chapter III, to disclose information 'in areas where reporting standards are still evolving', such as in the case of direct and indirect greenhouse gas emissions. Moreover, to complement the Guidelines, additional documents were published that provide guidance on responsible business conduct in the financial sector [24]. In particular, the OECD Guidance for Institutional Investors recommends that investors flag in their Responsible Business Conduct (RBC) policies that climate change risk is treated as a priority 'given the significant scale, scope and irremediable character of climate change impacts' [25]. It also encourages engaging in existing industry initiatives like the Carbon Disclosure Project, providing information on companies' greenhouse gas emissions and climate-related risks [25]. Although not perfectly aligned with the UNGPs, the OECD document on due diligence for banks [26] explains how a bank could potentially 'contribute' to an adverse impact, namely when the adverse impact of a client's activities or projects was foreseeable, when the proceeds were known or likely to be used by the client for high-risk activities and the bank's 'provision of the finance or underwriting service occurred without adequate due diligence' [26]. The document recognizes that 'for adverse impacts that are collective, diffuse and transboundary in nature such as climate change, a more nuanced analysis may be needed to understand the relationship between financing and the specific activities of the client causing harm' [26].

Overall, focusing on the text itself, both the UNGPs and the OECD Guidelines and accompanying documents fail to set explicit and ambitious standards related to climate 
change. However, since human rights and climate issues are closely related, these documents can be interpreted in ways that include the climate dimension. Moreover, complementing these key international instruments, the financial sector itself has developed its own guidance to tackle its human rights and environmental impacts.

\subsection{Private Guidance on Human Rights and Climate Applicable to Banks}

As seen, the UNGPs and the OECD Guidelines for Multinational Enterprises apply across sectors. Based on these documents, the banking sector itself has developed some guidance. In the narrow area of project finance, the Equator Principles, developed by financial institutions themselves and based on the International Finance Corporation performance standards [27], provide some important guidance. The Equator Principles are presented as 'a financial industry benchmark for determining, assessing and managing environmental and social risk in projects' [28]. Principle 2 on social and environmental assessment asks Equator Principles Financial Institutions (EPFIs) to require their client to conduct 'an appropriate Assessment process to address, to the EPFI's satisfaction, the relevant environmental and social risks and scale of impacts of the proposed Project'. The Assessment ought to include human rights and climate change risks (Principle 2). Annex A, titled 'Climate Change: Alternatives Analysis, Quantification and Reporting of Greenhouse Gas Emissions' provides additional guidance on how to calculate and communicate greenhouse gas emissions of a given project.

Beyond this project-by-project approach, the Thun Group, formed by some key players in the banking sector, have also developed broader guidance in the form of discussion papers, published in 2013 [29] and 2017 [30]. The papers, however, misinterpreted the corporate responsibility to respect human rights. They suggested, for example, that banks can generally not 'cause' or 'contribute to' human rights impacts through their clients, and that at most a bank can be said to be 'directly linked to' such impact [7]. This erroneous and limiting interpretation of the UNGPs prompted a reaction by key actors in the business and human rights field, notably the architect of the UNGPs, Professor John Ruggie [31]. Neither version of the discussion paper mentions climate change or reducing greenhouse gas emissions. They only refer to social and environmental risks, without further elaborating on the latter.

This brief overview of the most relevant standards applicable to the financial sector, of both public and private nature, highlights that the climate dimension is not well integrated into those standards. Yet, as shown in the next section, climate due diligence is an inherent dimension of human rights due diligence.

\section{Climate Due Diligence as an Inherent Dimension of Human Rights Due Diligence}

The UNGPs are rooted in international human rights law, and are to date the most authoritative normative standard at the international level concerning the responsibilities of corporations, as recognized by various actors [20,32-35]. This paper takes the view that, even though it is a soft law instrument, the unequivocally legal language and normative purpose of the UNGPs requires interpreting its content in the light of the legal categories it evokes-primarily those of international human rights law. In the same way as the international human rights obligations of states do not exist in a vacuum [36], the corporate responsibility to respect human rights must be interpreted, when relevant, also by reference to other bodies of law, including international environmental law and climate law. Although a self-standing human right 'to a stable climate' is not currently recognized under international law, the human rights implications of climate change, as noted earlier, are indisputable [37] and are starting to inform judicial decisions on the climate change-related legal duties of states [38] and corporations [20]. It is becoming increasingly clear that states need to address climate change and its harmful impacts as part of their obligations under international human rights treaties, which also entails due diligence obligations to regulate the private sector [39]. The European Court of Human Rights, which has produced significant jurisprudence on states human rights obligations in relation to environmental 
impacts [40,41], is now examining its first climate change-related application [42], and the Human Rights Committee is dealing with a similar case [43]. As state human rights obligations sometimes need to be interpreted in the light of environmental law and climate law principles, as well as taking stock of the indications of the most up-to-date climate science, so, too, the corporate responsibility to respect human rights should cover the climate change-related human rights impacts in which corporations are involved. Indeed, excluding the human rights harms and threats deriving from anthropogenic global warming from the normative reach of the corporate responsibility to respect would contradict one of the UNGPs' founding purposes, namely, to bridge the 'governance gaps created by globalization-between the scope and impact of economic forces and actors, and the capacity of societies to manage their adverse consequences' [44].

For these reasons, it is here argued that a principle of 'systemic integration' [45] as derived from the Vienna Convention on the Law of Treaties [46] should be applied to interpret the UNGPs' second pillar, reading the corporate responsibility to respect in the light of all relevant rules of international law, including environmental law and climate law principles [12]. This entails recognizing that the UNGPs principle of human rights due diligence contains a climate change dimension, that is referred to in this paper as climate due diligence. While the primary normative foundation of this principle under the UNGPs is international human rights law, in line with the normative basis of the UNGPs, climate due diligence is also informed by international instruments like the Paris Agreement, by climate science (particularly the work of the IPCC) and, possibly, by relevant principles of international environmental law (e.g., prevention). Clarifying this concept both as a standard of conduct and as a business process [47] is particularly urgent given current regulatory and judicial developments. The climate change responsibilities of corporations are under scrutiny worldwide and increasingly the target of climate change litigation $[12,48]$. The UNGPs, as the most authoritative standard of corporate responsibility at the international level, are being invoked in climate change litigation against businesses and, as seen above, have already been used by the District Court of The Hague to interpret the climate change-related legal obligations of Shell [20]. The upcoming EU Directive on mandatory human rights and environmental due diligence, which should be tabled by the European Commission in the last quarter of 2021, is likely to contain a climate change dimension, and might translate climate due diligence into a binding requirement for corporations, including banks, operating in and from the EU market [22]. Indeed, the Commission plans to adopt the Directive as part of its efforts to realize the European Green Deal's sustainability objectives [49], and the European Parliament, in its own 2021 proposal putting forward the text of a draft Directive, explicitly defines due diligence as including a climate change dimension [22].

Climate due diligence as a business process shares the main features of human rights due diligence, namely the fact that it is a flexible and adaptable device whose contents depend on factors like the severity of the risks identified, the size of the company, or the nature and context of its operations. Like the human rights due diligence process, therefore, climate due diligence necessarily starts with risk assessment. While human rights due diligence focusses on risks to the human rights of stakeholders, however, climate due diligence is centered on a company's direct or indirect impacts on the climate. As argued elsewhere [12,50], the two processes should not take place in silos, but rather communicate with, and complement each other. In conducting climate due diligence, a bank needs to understand, first of all, in what ways its own operations or its business relationships cause or contribute to climate change, and then take the necessary steps to address such risks. This crucial step, however, is not uncontroversial, as it requires understanding what it means to 'contribute' to anthropogenic global warming, a phenomenon that has been generated over the span of decades by the combined actions (and omissions) of a plethora of public and private actors.

In order to play a role in the energy transition and, possibly, comply with upcoming policy and regulatory developments, banks need to get a clear understanding of how not 
only their own operations, but also those of companies in their lending and investment portfolios might be contributing to anthropogenic global warming and to its adverse human rights impacts. The next section will address these questions.

\section{Climate Due Diligence: Understanding the Responsibilities of Banks}

A bank or institutional investor is typically involved in climate change impacts through its financial transactions with other companies, for instance a loan or minority shareholding. In order to determine whether its investments may constitute a breach of corporate responsibilities under the UNGPs, therefore, it is essential to understand when a company in its portfolio might be contributing to climate change. This assessment might seem problematic, in light of the global scope of the phenomenon and the high number of subjects that have contributed to it over time. This section aims at clarifying the issue before delving more specifically into the responsibilities of banks and unpacking the main elements of the climate due diligence process.

\subsection{Identifying the Relevant Impacts}

The first step of the human rights due diligence process is to identify and assess any actual or potential adverse human rights impacts with which corporations may be involved 'either through their own activities or as a result of their business relationships' [5]. For a bank this entails a double challenge, namely, identifying the impact of a client's activities on the climate and, consequently, assessing its own involvement in such impacts by means of its financing or lending to that client. The UNGPs' notions of 'impact' and 'risk' have the rights-holders as their focus, and not the protection of the company or of its shareholders' interests. Although not explicitly stated in the UNGPs, environmental damage which bears an impact on human rights constitutes a relevant part of the assessment stage of human rights due diligence. The importance of human rights risks assessment cannot possibly be overstated, as the identification of actual and potential impacts, as well as the type of connection that the corporation has to those impacts, determines the steps the corporation will be required to take and, in some cases, the remedy owed to the victims.

This step of the due diligence process, however, might be seen as particularly challenging when it comes to an enterprise's contribution to climate change, given the global scale of the phenomenon and the complex chains of causality that link anthropogenic global warming and specific human rights impacts. It is legitimate to wonder, first of all, whether it is possible to identify the 'victims' of climate change, which in practice requires establishing a causation link between climate change and specific human rights harms. Some of the effects of climate change are, indeed, extremely diffuse and hard to qualify as human rights violations with 'identifiable groups of victims who might seek compensation' [51]. However, also thanks to advancements in climate science, some consequences of anthropogenic global warming-for instance, glacier melting or sea-level rise-are today largely foreseeable and measurable, to the point that they give rise to specific state obligations in terms of prevention and redress of the actual and potential human rights impacts [51]. Climate change, therefore, does not only give rise to diffuse effects, but also to identifiable impacts on identifiable victims [52-54].

Even considering this, however, a second challenge emerges, in that the human rights impacts of climate change are typically the result of the actions and inaction, sedimented through time, of a plethora of public and private actors. It is not always straightforward for a corporation, therefore, to identify the link between its own contribution to climate change and a specific climate change-related adverse impact. Even more so for a bank lending to a company or project without retaining operational control over the client's activities. Whereas the goal of human rights risk assessment is to identify the impacts 'with which a business enterprise may be involved' and 'to understand the specific impacts on specific people, given a specific context of operations' [5], a corporation will not always be able to identify the specific climate change-related human rights impacts with which it is involved due to its contribution to climate change. It is here argued, however, that 
this element of uncertainty does not relieve corporations from assessing and addressing their own climate change impacts. This is for two reasons, that will be explained below: (i) while it cannot be predicted with certainty when and where the adverse human rights effects of climate change will materialize, their occurrence is virtually certain, and some of those impacts are already taking place; (ii) climate-change related human rights impacts tend to be large-scale, wide in scope and irremediable, a circumstance that calls, under the UNGPs, for prioritization in terms of due diligence actions.

As stated by the European Parliament in its recommendations for an EU-wide directive, 'due diligence is primarily a preventative mechanism' [22]. While responsibilities of mitigation and remediation may come into the picture once a harmful effect has materialized, the due diligence standard also concerns 'potential' impacts, establishing the corporate responsibility to identify and prevent foreseeable risks before they come into being. This preventative role is all the more essential in the case of 'severe' human rights impacts, which are defined, according to the UNGPs, based on their 'scale, scope and irremediable character' [5]. Some of the human rights impacts of climate change are already manifest, to the point that communities around the world are trying to leverage the responsibilities of states and corporations to obtain compensation for the harm suffered or for the costs of protecting themselves from climate change-related threats $[43,55]$. As mentioned above, attribution science [56] is now able to identify in anthropogenic global warming the cause of extreme weather events and other phenomena that are putting in danger the life, livelihoods and well-being of entire communities. There is also increasing evidence that such harmful effects are bound to become more frequent as global warming aggravates [57]. As a result, while a corporation contributing to climate change cannot accurately and exactly predict where and when the adverse impacts of climate change will result in specific human rights violations, it has the virtual certainty that such impacts will materialize, while some are already materializing. Although this will not necessarily be enough to establish liability in a court of law for climate change-related human rights impacts, it does trigger responsibility under the UNGPs. The preventative logic of the UNGPs' notion of due diligence depends on the assessment of (foreseeable) 'risk', which by definition entails a degree of indeterminacy [58]. Indeed, if it is true that 'preventive measures are [ ... ] intended to avert risks for which the cause-and-effect relationship is already known' [59], it is equally clear that 'uncertainty is obviously inherent in the very notion of risk', and that 'also quantifiable risks, where the likelihood and nature of an anticipated impact are relatively "established", still embody a degree of uncertainty" [58]. Notwithstanding this element of indeterminacy, scientific evidence about the causal link between greenhouse gases emissions, global warming and human rights impacts allows one to argue that a 'reasonable and prudent enterprise' [60], under the UNGPs, would identify and address the risk of contributing to climate change, all the more so because the UNGPs recommend that, when prioritization of actions is needed, corporations must 'first seek to prevent and mitigate those [impacts] that are most severe or where delayed response would make them irremediable', as many well-known consequences of climate change [5].

\subsection{Categories of Corporate Responsibility: What Does It Mean to 'Contribute' to Climate Change?}

The UNGPs constitute 'the global authoritative standard, providing a blueprint for the steps all states and businesses should take to uphold human rights' [61]. As such, they are concerned with establishing a standard of responsibility, not of liability. Responsibility under the UNGPs, therefore, can arise independently of whether liability could be established in a court of law for certain actions or omissions. The corporate responsibility to respect human rights is articulated in the UNGPs through three categories of involvement, namely 'causing', 'contributing to' and 'being linked to' human rights violations. The UNGPs use these categories to define corporate involvement in human rights violations, and not in environmental impacts per se. However, as explained above, climate change is a global phenomenon which is indisputably causing human rights impacts whose frequency and 
severity is bound to increase in the near future, thus constituting one of the main human rights threats of our time [2]. Given this indissoluble link between climate change and foreseeable and measurable (severe) human rights impacts whose origin can be scientifically attributed to anthropogenic global warming, the three categories can arguably be used to outline the responsibility of corporations, and of the financial sector in particular, in relation to climate change. There is little doubt, following the UNGPs' categorization, that no single corporation (or state) is 'causing' climate change. Causing responsibility emerges when a 'bank's actions and decisions on their own were sufficient to result in an adverse human rights impact, without the contribution of clients or other entities' [62]. This scenario is ruled out by the very nature of anthropogenic global warming, which derives from the cumulative historic emissions of a plurality of subjects [63], as well as, arguably, from the insufficient preventative and mitigating action undertaken by governments. The focus of the next sub-sections is, therefore, on 'contribution' and 'linked to' responsibility.

The Thun Group's interpretation referenced earlier in this article conflates the two categories of 'causing' and 'contributing' holding that contribution can arise only from the bank's own activities, and not from the provision of financial support to another entity [31]. This interpretation is not correct, as contribution responsibility can also result from a bank's relationship with a client. A bank might be 'contributing' to a human rights violation when its 'actions and decisions influenced the client in such a way as to make the adverse human rights impact more likely' [62]. Contribution, under the UNGPs, is a concept that implies an element of causality. An example of contribution responsibility could be a bank providing financing to a client for an infrastructure project leading to forced displacements when 'the bank knew or should have known that risks of displacement were present, yet it took no steps to seek to get its client to prevent or mitigate them' [62]. Importantly-and contrary to the Thun Group's contention that certain types of loans are inherently more problematic and require greater due diligence [31] — there is no preordained benchmark as to the type or size of financing that triggers contribution, the only indication given by the OHCHR being that the required 'element of causality may in practice exclude activities that have only a "trivial or minor" effect on the client' [62].

In the case of climate change, it must first of all be asked whether it is generally possible for a corporation to 'contribute' to it within the meaning of the UNGPs. This question will be answered in two parts, focusing first on the responsibility of the so-called 'big emitters' and then more generally on the nature of state and non-state responsibilities under the Paris Agreement.

The concept of contribution indicates acts and omissions that 'materially increase the risk of the specific impact which occurred even if they would not be sufficient, in and of themselves, to result in that impact' [64]. While it is not possible to fix a level of emissions that determines with certainty the existence of contribution responsibility, a reasoning can be made concerning the world's 'big emitters' —or 'carbon majors' - namely, those corporations that historically bear the greatest responsibility for human-produced greenhouse gas emissions. The so-called 'Carbon Majors petition' in the Philippines relied on climate science to list the world's fifty top emitters, detailing their individual shares of emissions in the period 1751-2010 [65]. Each of the ten highest-ranking companies in this list account for a share of historical human-produced emissions ranging from $0.5 \%$ to $3.5 \%$. The petition, presented to the Philippines Commission of Human Rights, argues that '[i]n accordance with the Guiding Principles, the Carbon Majors' activities have contributed to, or the Carbon Majors have been involved in, climate change related infringements of human rights' [65]. Through their emissions, these corporations 'have contributed to a consistently elevated level of atmospheric carbon dioxide', which, in turn, is responsible for current or predicted climate change impacts that 'have resulted and/or will likely result in the infringements of the people's human rights' [65]. Although the Commission's final report is not available yet, in a December 2019 statement it expressed the view that the Carbon Majors' contribution to climate change can potentially result in liability in the Philippines [66]. 
A 2017 report by CDP in collaboration with the Climate Accountability Institute, referring to the world's top 100 (private and public) fossil fuel producers since 1988, pointed out that ' $[t]$ he scale of historical emissions associated with these producers is large enough to have contributed significantly to climate change. It follows that the actions of these producers over the medium-long term can, and should, play a pivotal role in the global energy transition' [18]. If, as mentioned above, the largely undefined concept of contribution certainly entails an element of causality and excludes 'trivial or minor' effects, it seems that the historically significant contribution of at least the world's big emitters should fall in this category. As such, these companies' continued investment in the production of fossil fuels and in the exploration of new deposits seems incompatible with the responsibility to respect under the UNGPs. In a pending lawsuit in France, Total is accused of failing to align its policies with the Paris Agreement's goals and, among other things, to continue investing in the exploration of new oil deposits [67]. That these companies' investments are incompatible with the UNGPs is confirmed by the fact that such companies have known for decades [68] of the harmful effects of their activities on the climate and that they are now certainly aware that realizing the Paris mitigation goals requires drastic cutbacks on their emissions. It follows from these considerations that, as the next sub-sections will explain in more detail, for a bank or institutional investor, to retain a 'carbon major' in its portfolio raises a red flag and requires taking due diligence steps to carefully assess and address the risk of being directly linked or contributing to climate change.

While 'big emitters' should be considered high-risk due to the particularly severe climate change impact of their core business, it is important to specify that any projectsparticularly new projects or project expansions-bound to give rise to significant amounts of greenhouse gas emissions and to perpetuate unsustainable models of energy production potentially contribute to climate change within the meaning of the UNGPs. Indeed, given the urgency, according to current climate science, of cutting emissions of $7.6 \%$ per year $\left(1.5^{\circ} \mathrm{C}\right.$ goal) or at least of $2.7 \%$ per year $\left(2{ }^{\circ} \mathrm{C}\right.$ goal) from 2020 to 2030 [69,70], projects and investment setting back progress towards this objective in any significant manner would seem, prima facie, to be making the adverse impacts of climate change more likely. A bank financing such a project, therefore, should be aware of the risk of being the enabler of climate impacts in breach of its responsibility under the UNGPs. This does not mean, however, that all fossil fuel projects and investments therein can be dropped at once. In spite of the urgency and unavoidability of the energy transition, the latter cannot be achieved overnight, as suddenly abandoning fossil fuel energy would also have negative human rights and development implications.

It might be useful, in this respect, to look at the principle of progression enshrined in the Paris Agreement, under which each party to the Agreement commits 'to take all appropriate and adequate climate measures according to its responsibility and its best capabilities in order to progressively achieve the objective of the Agreement-to keep the increase in global temperature well below $2{ }^{\circ} \mathrm{C}^{\prime}$ [71]. Under the Paris Agreement, the principles of progression and of 'highest possible ambition' are combined to require states parties to 'go beyond previous efforts' with every successive National Determined Contribution (NDC) [71]. Whereas states parties retain ample choice of means regarding how to fulfil their due diligence responsibility, with due regard to their different capabilities, the principles of progression and highest possible ambition are at face value incompatible with any 'retrogressive' measures, meaning steps that halt or reverse progress towards realizing the goal. The principle of 'non-retrogression' is here borrowed from the doctrine elaborated by the UN Committee on Economic, Social and Cultural Rights (CESCR) to indicate that any retrogressive measures with regard to the progressive realization of rights are prima facie incompatible with the Covenant on Economic, Social and Cultural Rights and would need to be fully justified in the context of the full use of the maximum available resources [72]. It also implies that progress towards the goal must be based on concrete and measurable targets. In the historical Urgenda judgment, for instance, the court found that 
the Dutch policy to counter climate change fell short of the required level of ambition, and ordered the state to revise it [38]. This, in turn, will require the Netherlands to accelerate the closure of existing coal-fired plants [73]. Increasingly clear indications as to the concrete actions required by states and businesses come from climate science, for instance the recent International Energy Agency's warning that 'exploitation and development of new oil and gas fields must stop this year [2021] and no new coal-fired power stations can be built if the world is to stay within safe limits of global heating and meet the goal of net zero emissions by $2050^{\prime}$ [74].

In sum, while the global energy transition will happen gradually, (i) states must immediately take concrete, targeted and increasingly ambitious steps to curb emissions in line with the Paris Agreement and climate science; (ii) the balance between reducing emissions and meeting the energy demand will be struck differently based on the level of development and specific circumstances of each country [75]; (iii) in some cases, such balance will require the rapid dismantling of certain high-emitting activities and refraining from investing in/authorizing new ones. The Oslo Principles posit that 'States and enterprises must refrain from starting new activities that cause excessive GHG emissions, including, for example, erecting or expanding coal-fired power plants without taking countervailing measures, unless the relevant activities can be shown to be indispensable in light of prevailing circumstances, as might be the case, in particular, in the least developed countries' [36]. The reference to 'countervailing measures' seems of little relevance at the moment, given that technologies to remove $\mathrm{CO}_{2}$ from the atmosphere are still not available on a large scale [76].

In this perspective, if we accept that corporations have a climate due diligence responsibility under the UNGPs and that, as affirmed by Special Rapporteur Boyd, this also entails that 'businesses should support, rather than oppose, public policies intended to effectively address climate change' [77], corporations, based on their level of contribution to climate change, might have a responsibility to: (i) cut emissions, as established by a Dutch court in the 2021 Shell judgment (finding that Shell has a strict obligation to cut its emission of a mandated percentage by 2030) [20]. This might require phasing out existing projects and avoiding investing in new ones; (ii) aligning their company and/or group policies with the objectives of the Paris Agreement; (iii) cutting commercial ties with business partners who, unresponsive to climate due diligence efforts, continue to contribute to climate change.

Looking at contribution to climate change through the lenses of progressive realization helps defuse the possible misunderstanding that contribution responsibility under the UNGPs can only stem from uniquely sizable amounts of emissions such as those historically produced by the Carbon Majors. In fact, in line with the UNGPs, size is only one of the many factors to be taken into account in this assessment.

Based on the reasoning presented, a bank or institutional investor assessing the climate change impacts of their portfolios should consider that there is a strong presumption of 'contribution' for all those activities that hinder the progressive achievement of the reduction targets required to realize the Paris Agreement and are not justified by demonstrable reasons of necessity in the light of all available resources and alternative options and with due regard to all relevant human rights and sustainable development considerations. In examining their own portfolios, therefore, banks should be prepared to define 'detailed interim targets and specific timelines for sectoral portfolios to reach net-zero emissions by or before 2050' [78], and prioritize divestment from those companies and projects that are contributing to global warming in the sense just described.

According to the UNGPs, contribution can give rise to a responsibility of remediation [5]. In practice, should the issue be raised in a court of law, it would fall to the judge to assess the matter based on the applicable law and on all the circumstances of the case. Notwithstanding the legal challenges this may pose [79], it is worth recalling that climate change litigation against corporations (typically, against 'big emitters') is undergoing rapid developments that might clarify the link between climate change-related responsibility and liability in the coming years. As mentioned earlier, the 2021 landmark judgment against 
Shell in the Netherlands ordered a 45\% cut to the corporate group's emissions by 2030 as compared to 2019, showing that it is possible to attach liability to a company's contribution to climate change. Interestingly, the court interpreted Shell's unwritten standard of care under the Dutch Civil Code on the basis of, among other sources, international human rights law (the right to life and the right to private and family life), the UNGPs and other business and human rights soft law standards. While acknowledging Shell's publicly-stated support of the UNGPs, the court pointed out that '[d]ue to the universally endorsed content of the UNGP, it is irrelevant whether or not RDS has committed itself to the UNGP' [20], de facto underlining the normative character of the UNGPs, which sets them apart from the voluntary and optional nature of CSR initiatives. The increasingly recognized authority of the UNGPs as the golden standard of corporate conduct, able to inform the interpretation of legally binding norms at the domestic level, should encourage businesses, including in the financial sector, to carefully align their practices with such a standard.

\subsection{Banks: 'Contribution' or 'Linkage' to Climate Change?}

In the case of the financial sector, the question is whether a bank or investor can 'contribute' to climate change by investing in or lending to companies and projects that contribute to it. The short answer is yes, it is possible. However, there is no pre-defined amount of investment, as explained earlier in this paragraph, above which contribution can be said to arise, and the assessment will have to be made on a case-by-case basis. When the financial transaction bears a causal link to the adverse impacts, meaning that it influences the client to such an extent that it increases the likelihood of the adverse impact, then the bank might be in a position of contribution. The circumstances to be evaluated, in this respect, are not limited to the relative size of the transaction, but can include the type of investment and the degree of influence that the bank exercises over the client, the severity and foreseeability of the harm (which is generally high in the case of climate change), and, as will be discussed below, whether the bank knows about the climate change risk associated with a particular project and takes reasonable steps to prevent and mitigate such risk [62]. It is also worth reiterating that responsibility under the UNGPs can exist regardless of whether liability could be established in a court of law.

As pointed out by OHCHR, '[i]n practice, many of the impacts associated with a bank's financial products and services may fall into the 'direct linkage' category' [62]. Under the UNGPs, indeed, the corporate responsibility to respect does not only concern cases in which a causal link can be established between the corporations' actions or omissions and a specific human rights impact (as in the categories 'causing' or 'contributing to' human rights impacts) [5], but also cases in which the corporation is 'linked to' actual or potential human rights impacts whose occurrence it has not significantly influenced [62]. A typical scenario is the occasional arms-length sourcing of goods or products from suppliers which adopt exploitative labour practices. Although the buyer company does not control the supplier and its daily activities, it is linked to the abuses by its business relationship with the supplier and has, consequently, a responsibility to take human rights due diligence steps. The OHCHR has clarified that even non-controlling minority shareholding gives rise to a relevant 'business relationship' for the purpose of GP13(b) $[62,80]$. This entails that a bank has a responsibility to 'develop an understanding of its overall risk picture' [62], considering not only risks of 'contribution', but also of mere 'linkage' to adverse impacts due to the presence of companies or projects in their portfolios that contribute to climate change. 'Linked to' responsibility requires taking steps and seeking to prevent or mitigate the identified actual or potential impacts [5], giving priority to most severe ones [62]. Although this category of responsibility, according to the UNGPs, does not necessarily give rise to a responsibility of remediation, a bank that is aware that certain companies or projects in its lending portfolio are contributing to climate change and yet 'over time fails to take reasonable steps to seek to prevent or mitigate the impact ( ... ) could eventually be seen to be facilitating the continuance of the situation and thus be in a situation of "contributing"' to the violation [62]. In other words, 'linkage' and 'contribution' to adverse 
impacts are placed on a responsibility continuum, and a bank might shift from the former to the latter if it systematically fails to exercise due diligence [62]. While the UNGPs do not explicitly address climate due diligence, the fundamental elements of this process for banks can be inferred, with the necessary differences, from the human rights due diligence concept.

\subsection{The Climate Due Diligence of Banks}

As mentioned earlier, the due diligence process requires first assessing the risks. In this context, banks and other actors in the financial sector are required to assess the risk of contributing to climate change through their own activities or of being linked to it by their business relationships, including by their lending or investment portfolios. As pointed out by OHCHR, given that such portfolios might be large and complex, the bank or investor should have systems in place capable of ensuring 'a minimum level of screening for all types of activities, with the more detailed analysis prioritized for high-risk clients or transactions' [62]. As stated above, climate change is the actual and potential cause of severe human rights impacts, therefore the bank should carefully assess whether some businesses in its portfolio, due to the nature of their activities or other contextual elements, are contributing to it, and then assess its own involvement (contribution or direct linkage) [62]. As explained earlier, keeping carbon majors in the investment portfolio should be considered high-risk, and those investments should be prioritized for climate due diligence. Lending to new fossil-fuel projects or project expansions knowing that this will lead to an emission increase is also a high-risk activity and could constitute 'contribution' for the purpose of the UNGPs.

One of the challenges to be addressed by companies in the financial sector is to develop methodologies and processes to properly measure, address and communicate these risks. Although some guidance already exists [81-83], when this is insufficient, banks have a responsibility to develop specific indicators allowing them to measure both their direct and indirect (or 'Scope 3') emissions, as stated by the Dutch OECD National Contact Point in a decision concerning ING Bank [84]. There are signs that many European banks are stepping up their efforts to publish relevant data 'on criteria such as lending to fossil fuel industries, as Europe's central banks scrutinize their loan books and threaten higher capital requirements for those with excessive climate risks' [85]. However, disclosure only concerns a limited portion of the banks' business and does not follow uniform standards or methods [85].

Another challenge is that stakeholder engagement throughout the due diligence process is particularly problematic in the case of climate due diligence, given the large scale and global nature of the impacts considered. In this respect, the OECD general due diligence guidance (2018) recommends engagement with 'credible stakeholder representatives or proxy organisations (e.g., NGOs, representative public bodies, etc.)', as well as with 'experts on specific issues or contexts', such as academics, NGOs, or local organisations, for advice on how to develop and implement due diligence activities [86].

It is important to underline that climate change risk assessment and human rights risk assessment should not exist in separate silos, but rather feed into each other in a way that ensures coherence and mutual reinforcement. Indeed, for instance, projects intended to facilitate the energy transition might in turn have negative human rights implications, as in the food security impacts of biofuel production [87]. Hydroelectric projects, which can mitigate climate change due to their low emissions, 'often lead to displacement of local people and the destruction of ecosystems upon which they depend, and can also harm the health and livelihoods of people living downstream from the project by reducing river flows ' [2]. Looking at this impact from a human rights perspective leads to identifying possible violations of a number of rights, including the right to housing, the right to an adequate standard of living and the right to food. At the same time, human rights risk assessment should take into consideration the climate change-related vulnerabilities of 
stakeholders in order to fully grasp the actual and potential negative impacts of an activity or project and their severity.

According to the UNGPs, human rights due diligence requires exercising leverage over business partners in order to prevent or mitigate harmful impacts that those subjects are causing or contributing to. Leverage, which consists in the ability to effect change in the business partner's practices, could be exercised by a bank or investor in several ways, for instance through the exercise of voting rights, attendance at general meetings, direct contacts with clients or investee companies, as well as through collaboration with other banks and investors aimed at increasing leverage [25]. As concerns shareholders, a recent example shows how they can put pressure on companies to adopt climate change strategies. One of ExxonMobil shareholders, the activist hedge fund Engine No. 1, managed to rally support from other shareholders, including the three biggest U.S. pension funds, and place two independent directors in the company's 12-member board [88]. The 'coup' stemmed from the shareholder unhappiness with the company's strategy around climate change and with its resistance to gradually shift to renewables, an attitude that is not only incompatible with corporate responsibilities under the UNGPs, but also increasingly risky from a financial perspective [89]. The OECD document on due diligence for banks also exemplifies a possible avenue for a bank to exercise leverage by raising the so-called 'business case' with its clients:

'in cases of securities underwriting, if a company in a carbon intensive industry does not consider climate change to be a risk because there is no foreseeable short-term impact on the company, the bank can play a role in explaining to the client the significant environmental and social risks that climate change poses and how it may also have a material impact on the client, for example due to changing investor sentiment and increasing regulation.' [26]

In addition, a bank's expectations in terms of social and environmental standards (or $\mathrm{RBC}$, as per the OECD's jargon) can 'be included where possible in financing contracts or underwriting agreements' to incentivize the client's compliance, and also included in dedicated trainings [26].

Although banks have many avenues to try and exercise their leverage, when their efforts do not succeed in influencing the client's conduct, the last-resort option is ending the business relationship [5]. Indeed, the concept of due diligence, in line with its definition under international human rights law and 'as defined under UNGP 13(b), whilst constituting a standard of conduct, must be clearly targeted towards the achievement of the intended results' [90]. It cannot, therefore, be reduced to a box-ticking exercise to be carried out indefinitely without seeing change, especially when the identified impacts are severe $[5,90]$. Divestment from climate change-contributing businesses and projects is a growing wave, with fossil fuel divestment constituting 'a \$14.5 trillion movement with over a thousand major investors, pension plans, and endowments committed' [91]. While different motivations can drive a divestment decision, including of course financial considerations, divestment becomes a responsibility under the UNGPs when the investor's direct link or contribution to adverse impacts cannot be effectively addressed through the exercise of climate due diligence. It is also worth noting that, under the UNGPs, a company's failure to address negative impacts cannot be offset by parallel positive initiatives in other fields [5]. For instance, a bank or investor failing to exercise leverage on (or divest from) high-emitting companies in its portfolio cannot compensate for this failure by increasing its 'green' investments or financing climate adaptation projects. Similarly, emitting companies cannot discharge their responsibilities under the UNGPs by buying carbon offsets, and not only for the 'long history of overpromising and underdelivering' of these projects [92], but also because the corporate responsibility to respect under the UNGPs cannot be outsourced [12,93].

Finally, the UNGPs require honest communication to the public of the outcomes of risk assessment, of the due diligence steps undertaken and of their effectiveness. In the context of climate change litigation, failure to disclose relevant information or, worse, to 
actively mislead the public and/or a company's shareholders as to the climate change impacts of a company's activities can lead to liability [65]. Disclosure should not only cover a company's own activities, but also the risks associated with 'all major subsidiaries and affiliates' and, if practicable, with the corporation's supply chains, or investment and lending portfolios [94].

\section{Conclusions}

This article has provided a conceptualization of the climate change responsibilities of banks under the UNGPs. It has argued that banks have a responsibility under the UNGPs to identify, measure and address their direct or indirect involvement in impacts that further the worsening of global warming and its inevitable human rights consequences. The now widely-accepted human rights due diligence standard elaborated by the UNGPs, interpreted in the light of relevant standards of international environmental law and climate law, provides the strongest normative basis and the clearest definition to the principle of climate due diligence, presented in Section 4 of this article.

Understanding the exact contours of this responsibility is essential for banks to be best prepared for upcoming regulatory developments on mandatory due diligence and disclosure, as well as to play their role as key enablers of the energy transition. We have shown in this paper that banks face a double challenge, in that they need to identify their clients' impacts on climate change and, consequently, assess to what extent they might be contributing or linked to such impacts by their own financial transactions to those clients. This risk assessment step poses significant difficulties, especially in the absence of universal methodologies for measuring indirect emissions. This article has explained what it means, for the purpose of the UNGPs, to 'contribute' to climate change, highlighting that some activities and projects are under a strong presumption of incompatibility with both the principles of progression and highest possible ambition underlying the Paris Agreement and with corporate responsibilities under the UNGPs.

Knowing whether companies in their portfolios are contributing to climate change, in turn, allows banks to assess their own involvement, and to distinguish between 'contribution' type and 'directly linked to' type of responsibility. Retaining certain high-emitting companies and projects in a bank's portfolio raises red flags and requires taking due diligence steps to carefully assess and address the risk of being directly linked or contributing to climate change through its financial transaction. Although banks will in most cases only have indirect involvement in these impacts through their financial transactions, there might be cases in which, for instance, their financing to a high-emitting project is so crucial or their influence over the client is so relevant that a causal link might be established between their financial transaction and the adverse impacts ('contribution' type of involvement). Even when they are only directly linked to the impacts, they are required to exercise leverage over the client and, possibly, end the business relationship (e.g., divestment) when their efforts fail to mitigate the climate change impacts of the client's activities.

For instance, it seems clear that, based on current climate science, in order to align their portfolios with the Paris Agreement and be compliant with the UNGPs, banks should avoid financing new fossil fuel projects or 'any company that is expanding fossil fuel extraction or infrastructure, or exploring for new reserves' [95]. Attribution science nowadays has 'the ability to link global warming to the intensity of storms, rising sea levels and worsening heatwaves combined with the ability to trace historical emissions to individual companies dating back to the Industrial Revolution' [96], making it easier than in the past to identify the exact impact of a client on global warming. Several banks have already announced ambitious plans to align their portfolios with the Paris Agreement, for instance by phasing out their finance for coal or withdrawing financing from carbon majors that do not have a credible transition plan [95]. In most cases, however, such pledges are too vague and lack specific targets and indicators, failing to establish a clear commitment to cease investing in fossil fuel projects [96]. Banks should be aware that taking concrete and targeted steps in this respect is not only a way to shield the bank from future financial risks, but also the only 
way to comply with their responsibility under the UNGPs. They should build on growing international guidance and adopt collaborative approaches to further define methodologies and indicators able to grasp the links between their portfolios and climate change.

Author Contributions: Conceptualization; methodology; investigation; writing-original draft preparation; writing-review and editing, C.M. and N.B. All authors have read and agreed to the published version of the manuscript.

Funding: This research received no external funding.

Conflicts of Interest: The authors declare no conflict of interest.

\section{References}

1. Paris Agreement. 2016. Art. 2.1(c). Available online: https://unfccc.int/files/essential_background/convention/application/ pdf/english_paris_agreement.pdf (accessed on 8 July 2021).

2. UNEP. Climate Change and Human Rights. 2015. Available online: https://wedocs.unep.org/bitstream/handle/20.500.11822/9 530/-Climate_Change_and_Human_Rightshuman-rights-climate-change.pdf.pdf?sequence $=2 \& a m p \% 3$ BisAllowed $=($ accessed on 8 July 2021).

3. Culp, S. Banks Increasingly See Climate Risk as Top Priority. Forbes, 29 June 2021. Available online: https://www.forbes.com/ sites / steveculp/2021/06/29/banks-increasingly-see-climate-risk-as-top-priority/?sh=30c51f4258fe (accessed on 8 July 2021).

4. Reghezza, A.; Altunbas, Y.; Marques-Ibanez, D.; Rodriguez d'Acri, C.; Spaggiari, M. Do Banks Fuel Climate Change? European Central Bank Working Papers Series. Available online: https://www.ecb.europa.eu/pub/pdf/scpwps/ecb.wp2550 \{\}24c25d579 1.en.pdf (accessed on 8 July 2021).

5. United Nations (UN). Guiding Principles on Business and Human Rights: Implementing the United Nations 'Protect, Respect and Remedy' Framework; A/HRC/17/31; United Nations: New York, NY, USA, 2011.

6. Bernaz, N. Business and Human Rights. History Law and Policy. Bridging the Accountability Gap; Routledge: Abington, PA, USA, 2017.

7. Van Ho, T.L.; Alshaleel, M.K. The mutual fund industry and the protection of human rights. Hum. Rights Law Rev. 2018, 18, 1-29. [CrossRef]

8. De Felice, D. Banks and human rights due diligence: A critical analysis of the Thun Group's discussion paper on the UN Guiding Principles on Business and Human Rights. Int. J. Hum. Rights 2015, 19, 319-340. [CrossRef]

9. Macchi, C.; Van Ho, T.L.; Yanes, F. Investor Obligations in Occupied Territories: A Report on the Norwegian Government Pension Fund-Global. Essex Business and Human Rights Project, 24 April 2019. Available online: https: //www.essex.ac.uk/-/media/documents/research/ebhr/investor-obligations-in-occupied-territories--report-on-thenorwegian-government-pension-fund--globa.pdf (accessed on 8 July 2021).

10. Dowell-Jones, M.; Kinley, D. Minding the gap: Global finance and human rights. Ethics Int. Aff. 2011, 25, 183-210. [CrossRef]

11. Dowell-Jones, M. International finance and human rights: Scope for a mutually beneficial relationship. Glob. Policy 2012, 3, 467-470. [CrossRef]

12. Macchi, C. The climate change dimension of business and human rights: The gradual consolidation of a concept of 'climate due diligence. Bus. Hum. Rights J. 2021, 6, 93-119. [CrossRef]

13. OECD. Guidelines on Multinational Enterprises; OECD Publishing: Paris, France, 2011.

14. Van Ho, T.L. Defining the relationships: 'cause, contribute, and directly linked to' in the UN Guiding Principles on Business and Human Rights. Hum. Rights Q. 2021, 43. in press.

15. United Nations Website, UN at 75. Available online: https://www.un.org/en/un75/climate-crisis-race-we-can-win (accessed on 1 June 2021).

16. Birchall, D. Corporate power over human rights: An analytical framework. Bus. Hum. Rights J. 2021, 6, 58. [CrossRef]

17. Van de Venis, J.; Feiring, B. Climate Change—A Human Rights Concern; The Danish Institute for Human Rights: Copenhagen, Denmark, 2016; Available online: https://www.humanrights.dk/sites/humanrights.dk/files/media/migrated/final_dihr_hr_ and_cc_paper_3_11_16.pdf (accessed on 1 June 2021).

18. Griffin, P. The Carbon Majors Database: CDP Carbon Majors Report 2017. Available online: https://climateaccountability.org/ pdf/CarbonMajorsRpt2017\%20Jul17.pdf (accessed on 1 June 2021).

19. Toft, K.H. Climate change as a business and human rights issue: A proposal for a moral typology. Bus. Hum. Rights J. 2020, 5, 1-27. [CrossRef]

20. District Court of The Hague, Milieudefensie et al v Royal Dutch Shell PLC C/09/571932/HA ZA 19-379, 26 May 2021. English Version. Available online: https://uitspraken.rechtspraak.nl/inziendocument?id=ECLI:NL:RBDHA:2021:5339 (accessed on 1 June 2021).

21. French Parliament. Loi No 2017-399 du 27 Mars 2017 Relative au Devoir de Vigilance des Sociétés Mères et des Entreprises Donneuses d'ordre; French Parliament: Palais, France, 2017.

22. European Parliament, Resolution of 10 March 2021 with Recommendations to the Commission on Corporate Due Diligence and Corporate Accountability (2020/2129(INL)). Available online: https://www.europarl.europa.eu/doceo/document/TA-9-2021-0 073_EN.html (accessed on 26 July 2021). 
23. OECD. OECD Declaration and Decisions on International Investment and Multinational Enterprises. Available online: https: //www.oecd.org/investment/mne/oecddeclarationanddecisions.htm (accessed on 1 June 2021).

24. OECD. Responsible Business Conduct in the Financial Sector. Available online: https://mneguidelines.oecd.org/rbc-financialsector.htm (accessed on 1 June 2021).

25. OECD. Responsible Business Conduct for Institutional Investors. Key Considerations for Due Diligence under the OECD Guidelines for Multinational Enterprises. 2017. Available online: https://mneguidelines.oecd.org/RBC-for-InstitutionalInvestors.pdf (accessed on 8 July 2021).

26. OECD. Due Diligence for Responsible Corporate Lending and Securities Underwriting Key Considerations for Banks Implementing the OECD Guidelines for Multinational Enterprises. 2019. Available online: http:/ /mneguidelines.oecd.org/due-diligencefor-responsible-corporate-lending-and-securities-underwriting.pdf (accessed on 8 July 2021).

27. International Finance Corporation. Performance Standards on Environmental and Social Sustainability. 2012. Available online: https:/ / www.ifc.org/wps/wcm/connect/24e6bfc3-5de3-444d-be9b-226188c95454/PS_English_2012_Full-Document. pdf?MOD=AJPERES\&CVID=jkV-X6h (accessed on 1 June 2021).

28. Equator Principles. 2020. Available online: https://equator-principles.com/wp-content/uploads/2020/05/The-EquatorPrinciples-July-2020-v2.pdf) (accessed on 1 June 2021).

29. The Thun Group of Banks. UN Guiding Principles on Business and Human Rights, Discussion Paper for Banks on Implications of Principles 16-21. 2013. Available online: https:/ /www.skmr.ch/cms/upload/pdf/131002_Thun_Group_Discussion_Paper_ Final.pdf (accessed on 1 June 2021).

30. The Thun Group of Banks. Paper on the Implications of UN Guiding Principles $13 \mathrm{~b} \& 17$ in a Corporate and Investment Banking Context. 2017. Available online: https://media.business-humanrights.org/media/documents/files/documents/2017_12_Thun_ Group_of_Banks_Paper_UNGPs_13b_and_17.pdf (accessed on 1 June 2021).

31. Ruggie, J. Comments on the Thun Group of banks' Discussion Paper on the Implications of UN Guiding Principles 13 and 17 in a Corporate and Investment Banking Context. 21 February 2017. Available online: https:/ / media.business-humanrights.org/ media / documents / files/documents/Thun_Final.pdf (accessed on 8 July 2021).

32. Jägers, N. UN Guiding Principles at 10: Permeating narratives or yet another silo? Bus. Hum. Rights J. 2021, 1-14. [CrossRef]

33. Ramasastry, A. Advisors or enablers? bringing professional service providers into the Guiding Principles fold. Bus. Hum. Rights J. 2021, 1-19. [CrossRef]

34. UN General Assembly. Report of the Working Group on the Issue of Human Rights and Transnational Corporations and Other Business Enterprises, 16 July 2018. A/73/163. Available online: https:/ / undocs.org/A/73/163 (accessed on 26 July 2021).

35. Amnesty International Canada. Factum of the Intervenor. Choc v. Hudbay Minerals Inc., 2013, CV-10-411159. Available online: https:/ / www.amnesty.ca/sites/amnesty/files/imce/images/HudBay\%20factum.20feb2013.pdf (accessed on 19 July 2021).

36. Expert Group on Global Climate Obligations. Oslo Principles on Global Climate Obligations; Eleven International Publishing: The Hague, The Netherlands, 2015.

37. UN International Human Rights Instruments. Statement on Human Rights and Climate Change, 2020. HRI/2019/1, para 10. Available online: https://www.ohchr.org/Documents/HRBodies/CESCR/HRI_2019_1_AEV.docx (accessed on 26 July 2021).

38. The State of the Netherlands v Urgenda Foundation, Judgment of 20 December 2019, ECLI:NL:HR:2019:2007, $19 / 00135$.

39. UN General Assembly. Human Rights Obligations Relating to the Enjoyment of a Safe, Clean, Healthy and Sustainable Environment, 2019. A74/161, paras 58, 61. Available online: https://undocs.org/en/A/74/161 (accessed on 26 July 2021).

40. ECtHR. López Ostra v. Spain, App. no. 16798/90; 1994; ECtHR. Öneryildiz v Turkey, App. no. 48939/99; 2004.

41. ECtHR. Tătar v Romania, App. no. 67021/01; 2009.

42. Sabin Center for Climate Change Law. Youth for Climate Justice v Austria et al.; 2020. Available online: http://climatecasechart. com/non-us-case/youth-for-climate-justice-v-austria-et-al/ (accessed on 1 June 2021).

43. Sabin Center for Climate Change Law. Petition of Torres Strait Islanders to the United Nations Human Rights Committee Alleging Violations Stemming from Australia's Inaction on Climate Change. 2019. Available online: http: / / climatecasechart.com/non-us-case/petition-of-torres-straitislanders-to-the-united-nations-human-rights-committeealleging-violations-stemming-from-australias-inaction-onclimate-change/ (accessed on 1 June 2021).

44. Human Rights Council. Protect, Respect and Remedy: A Framework for Business and Human Rights, 2008. A/HRC/8/5, para. 3. Available online: https://www2.ohchr.org/english/bodies/hrcouncil/docs/8session/A-HRC-8-5.doc (accessed on 26 July 2021).

45. UN General Assembly. Fragmentation of International Law: Difficulties Arising from the Diversification and Expansion of International Law, 2006. A/CN.4/L.682. Available online: https://legal.un.org/ilc/documentation/english/a_cn4_1682.pdf (accessed on 8 July 2021).

46. Vienna Convention on the Law of Treaties, 1155 UNTS 331, 1969.

47. Bonnitcha, J.; McCorquodale, R. The concept of 'due diligence' in the UN Guiding Principles on business and human rights. Eur. J. Int. Law 2017, 28, 899-919. [CrossRef]

48. Sabin Center for Climate Change Law. Climate Change Litigation Databases. Available online: http:/ / climatecasechart.com/ climate-change-litigation/ (accessed on 1 June 2021). 
49. Fox, B. New Human Rights Laws in 2021, Promises EU Justice Chief Euractiv. 30 April 2020. Available online: https:// www.euractiv.com/section/global-europe/news/new-human-rights-laws-in-2021-promises-eu-justice-chief/ (accessed on 19 July 2021).

50. Olawuyi, D.S. The Human Rights-Based Approach to Carbon Finance; Cambridge University Press: Cambridge, UK, 2016 ; p. 407.

51. Farber, D.A. Basic Compensation for Victims of Climate Change. 155 U. PA. L. Rev. 2007, 155, 1605-1656. [CrossRef]

52. Otto, F.; James, R.; Allen, M. The Science of Attributing Extreme Weather Events and Its Potential Contribution to Assessing Loss and Damage Associated with Climate Change Impacts; Environmental Change Institute: Oxford, UK, 2014; Available online: https://unfccc.int/files/adaptation/workstreams/loss_and_damage/application/pdf/attributingextremeevents.pdf (accessed on 8 July 2021).

53. Swain, D.L.; Singh, D.; Touma, D.; Diffenbaugh, N.S. Attributing Extreme Events to Climate Change: A New Frontier in a Warming World. One Earth 2020, 2, 522-527. [CrossRef]

54. Marzeion1, B.; Cogley, J.G.; Richter, K.; Parkes, D. Attribution of global glacier mass loss to anthropogenic and natural causes. Science 2014, 345, 919-921. [CrossRef] [PubMed]

55. Sabin Center for Climate Change Law. Lliuya v RWE AG, Case No. 2 O 285/15 Essen Regional Court. Available online: http:/ / climatecasechart.com/non-us-case/lliuya-v-rwe-ag/ (accessed on 1 June 2021).

56. CarbonBrief. Attributing Extreme Weather to Climate Change. Available online: https://www.carbonbrief.org/mapped-howclimate-change-affects-extreme-weather-around-the-world (accessed on 1 June 2021).

57. Jordan, R. Stanford Researcher Reveals Influence of Global Warming on Extreme Weather Events Has Been Frequently Underestimated. Stanford News. 2020. Available online: https:/ /news.stanford.edu/2020/03/18/climate-change-means-extremeweather-predicted/ (accessed on 1 June 2021).

58. Trouwborst, A. The relationship between the precautionary principle and the preventative principle in international law and associated questions. Erasmus Law Rev. 2009, 2, 105.

59. De Sadeleer, N. Environmental Principles: From Political Slogans to Legal Rules; Oxford University Press: Oxford, UK, 2002; pp. 74-75.

60. Office of the UN High Commissioner for Human Rights. The Corporate Responsibility to Respect Human Rights: An Interpretive Guide; United Nations: Geneva, Switzerland, 2012; p. 4.

61. Ruggie, J.G.; Sherman, J.E. The Concept of ‘Due Diligence' in the UN Guiding Principles on Business and Human Rights: A Reply to Jonathan Bonnitcha and Robert McCorquodale. Eur. J. Int. Law 2017, 28, 921. [CrossRef]

62. Office of the UN High Commissioner for Human Rights. Response to Request from BankTrack for Advice Regarding the Application of the UNGP in the Context of the Banking Sector; 2017; p. 8. Available online: https://www.ohchr.org/Documents/ Issues/Business/InterpretationGuidingPrinciples.pdf (accessed on 1 June 2021).

63. Frumhoff, P.C.; Heede, R.; Oreskes, N. The climate responsibilities of industrial carbon producers. Clim. Change 2015, 132, 157-171. [CrossRef]

64. Debevoise \& Plimpton; Enodo Rights. Practical Definitions of Cause, Contribute and Directly Linked to Inform Business Respect for Human Rights. Discussion Draft. 2017. Available online: https://media.business-humanrights.org/media/documents / files/ documents/Debevoise-Enodo-Practical-Meaning-of-Involvement-Draft-2017-02-09.pdf (accessed on 1 June 2021).

65. Greenpeace Southeast Asia and Philippine Rural Reconstruction Movement. Petition-Requesting for Investigation of the Responsibility of the Carbon Majors for Human Rights Violations or Threats of Violations Resulting from the Impacts of Climate Change. 2015. Available online: https:/ / storage.googleapis.com/planet4-philippines-stateless/2019/05/5a38951a-5a38951acc-hr-petition_public-version.pdf (accessed on 1 June 2021).

66. Sabin Center for Climate Change Law. In re Greenpeace Southeast Asia and Others. Available online: http:/ / climatecasechart. com/climate-change-litigation/non-us-case/in-re-greenpeace-southeast-asia-et-al/ (accessed on 8 July 2021).

67. Notre Affaire A Tous; Sherpa; Les Eco Maires; ZEA. 13 French Local Authorities and 4 NGOs Ask the French Oil Company Total to Prevent Global Warming. 2018. Available online: https:/ / notreaffaireatous.org/wp-content/uploads/2018/10/Dossier-dePress-2F-Englishversion.pdf (accessed on 1 June 2021).

68. Grasso, M. Towards a broader climate ethics: Confronting the oil industry with morally relevant facts. Energy Res. Soc. Sci. 2020, 62, 101383. [CrossRef]

69. IPCC. Global Warming of $1.5^{\circ} \mathrm{C}$. An IPCC Special Report on the Impacts of Global Warming of $1.5^{\circ} \mathrm{C}$ Above Pre-Industrial Levels and Related Global Greenhouse Gas Emission Pathways, in the Context of Strengthening the Global Response to the Threat of Climate Change, Sustainable Development, and Efforts to Eradicate Poverty-Summary for Policymakers. 2018. Available online: https:/ / www.ipcc.ch/site/assets/uploads/sites/2/2019/05/SR15_SPM_version_report_LR.pdf (accessed on 1 June 2021).

70. UNEP. Emissions Gap Report 2019; UNEP: Nairobi, Kenya, 2019; p. 26. Available online: https://wedocs.unep.org/bitstream/ handle/20.500.11822/30797/EGR2019.pdf?sequence=1\&isAllowed=y (accessed on 1 June 2021).

71. Voigt, C.; Ferreira, F. 'Dynamic Differentiation': The Principles of CBDR-RC, Progression and Highest Possible Ambition in the Paris Agreement. Transnatl. Environ. Law 2016, 5, 285-303. [CrossRef]

72. CESCR. General Comment 3-The Nature of States Parties Obligations; 1990. E/1991/23; para 9. Available online: https: / / www.refworld.org/pdfid/4538838e10.pdf (accessed on 26 July 2021).

73. Karagiannopoulos, L. Dutch Government Tells Vattenfall to Shut 650 mw Coal Plant by End-2019. Reuters, 8 March 2019. Available online: https:/ / www.reuters.com/article/us-netherlands-coal-vattenfall/dutch-government-tells-vattenfall-toshut650-mw-coal-plant-by-end-2019-idUSKCN1QP1ZI (accessed on 1 June 2021). 
74. Harvey, F. No New Oil, Gas or Coal Development if World Is to Reach Net Zero by 2050, Says World Energy Body. The Guardian. 18 May 2021. Available online: https:/ / www.theguardian.com/environment/2021/may/18/no-new-investment-in-fossil-fuelsdemands-top-energy-economist (accessed on 1 June 2021).

75. Pieter Pauw, P.; Mbeva, K.; van Asselt, H. Subtle differentiation of countries' responsibilities under the Paris Agreement. Palgrave Commun. 2019, 5, 86. [CrossRef]

76. Shepherd, J. Can't We Just Remove Carbon Dioxide from the Air to Fix Climate Change? Not Yet. The Conversation, 3 August 2015. Available online: https:/ / theconversation.com/cant-we-just-remove-carbon-dioxide-from-the-air-to-fix-climate-changenot-yet-45621 (accessed on 8 July 2021).

77. United Nations (UN). Safe Climate-A Report of the Special Rapporteur on Human Rights and the Environment; 2019. A/74/161; para 72. Available online: https://www.ohchr.org/Documents/Issues/Environment/SREnvironment/Report.pdf (accessed on 8 July 2021).

78. Rothstein, S.M.; Saccardi, D. Climate Change Threatens U.S. Banks far More Than They're Disclosing. CNBC. Available online: https:/ / www.cnbc.com/2020/10/19/climate-change-threatens-banks-far-more-than-theyre-disclosing.html (accessed on 8 July 2021).

79. Savaresi, A.; Hartmann, J. Using Human Rights Law to Address the Impacts of Climate Change: Early Reflections on the Carbon Majors Inquiry. 2018. Available online: https:/ / ssrn.com/abstract=3277568 (accessed on 1 June 2021).

80. OECD. Scope and Application of 'Business Relationships' in the Financial Sector under the OECD Guidelines for Multinational Enterprises; OECD: Paris, France, 2014; Available online: https://mneguidelines.oecd.org/global-forum/GFRBC-2014-financial-sectordocument-2.pdf (accessed on 1 June 2021).

81. ADEME. Understanding the Issues around Quantifying GHG Emissions in the Financial Sector. 2016. Available online: https://www.banktrack.org/download/understanding_the_issues_around_quantifying_ghg_emissions_in_the_financial_ sector_1/fichier_v_1_eng_understanding_the_issues_around_quantifying_ghg_emissions_in_the_financial_sector.pdf (accessed on 1 June 2021).

82. Greenhouse Gas Protocol. Technical Guidance for Calculating Scope 3 Emissions Supplement to the Corporate Value Chain (Scope 3)-Accounting \& Reporting Standard; World Resources Institute \& World Business Council for Sustainable Development: 2013; p. 136. Available online: https://ghgprotocol.org/sites/default/files/standards/Scope3_Calculation_Guidance_0.pdf (accessed on 1 June 2021).

83. Teubler, J.; Kühlert, M. Financial Carbon Footprint: Calculating Banks' Scope 3 Emissions of Assets and Loans. In ECEEE Industrial Summer Study Proceedings; Wuppertal Institute for Climate, Environment and Energy: Wuppertal, Germany, 2020; p. 381. Available online: https:/ / epub.wupperinst.org/frontdoor/deliver/index/docId/7587/file/7587_Teubler.pdf (accessed on 1 June 2021).

84. Dutch NCP. Final Statement-Oxfam Novib, Greenpeace Netherlands, BankTrack and Friends of the Earth Netherlands (Milieudefensie) versus ING; 2019; p. 5. Available online: https://www.oecdguidelines.nl/documents/publication/2019/04/19 /ncp-final-statement-4-ngos-vs-ing (accessed on 8 July 2021).

85. Halftermeyer, M.; Comfort, N.; Pogkas, D. European Banks' Next Big Problem? The $\mathrm{CO}_{2}$ in Their Loan Books. Bloomberg. Available online: https:/ / www.bloomberg.com/graphics/2021-european-banks-fossil-fuels-climate-change-green-financing/ (accessed on 8 July 2021).

86. OECD. Due Diligence Guidance for Responsible Business Conduct. 2018. Available online: Http://mneguidelines.oecd.org/ OECD-Due-Diligence-Guidance-for-Responsible-Business-Conduct.pdf (accessed on 8 July 2021).

87. Choidas, E.; Cunha, L.; Owens, R. Human rights and green finance: Friends or foes? EurActiv, 22 August 2019. Available online: https:/ / www.euractiv.com/section/energy-environment/opinion/human-rights-and-green-finance-friends-or-foes/ (accessed on 1 June 2021).

88. Mufson, S. A Bad Day for Big Oil. The Washington Post, 27 May 2021. Available online: https:/ /www.washingtonpost.com/ climate-environment/2021/05/26/exxonmobil-rebel-shareholders-win-board-seats / (accessed on 1 June 2021).

89. Helman, C. Shareholders Rebuke Exxon Mobil on Climate, in a Wake-Up Call for Big Oil. Forbes, 27 May 2021. Available online: https:/ / www.forbes.com/sites/christopherhelman/2021/05/27/shareholders-rebuke-exxonmobil-on-climate-in-awake-up-call-for-big-oil/?sh=1946a6751e41 (accessed on 1 June 2021).

90. Macchi, C.; Bright, C. Hardening soft law: The implementation of Human Rights Due Diligence requirements in domestic legislations. In Legal Sources in Business and Human Rights: Evolving Dynamics in International and European Law; Magi, L., Buscemi, M., Russo, D., Lazzerini, N., Eds.; Brill: Leiden, The Netherlands, 2020; pp. 218-247.

91. Carlin, D. The Case for Fossil Fuel Divestment. Forbes, 20 February 2021. Available online: https://www.forbes.com/sites/ davidcarlin/2021/02/20/the-case-for-fossil-fuel-divestment/?sh=7d09c6bc76d2 (accessed on 1 June 2021).

92. Irfan, U. Can You Really Negate Your Carbon Emissions? Carbon Offsets, Explained. Vox, 27 February 2020. Available online: https:/ / www.vox.com/2020/2/27/20994118/carbon-offset-climate-change-net-zero-neutral-emissions (accessed on 1 June 2021).

93. Seck, S.L. Climate Change, Corporate Social Responsibility, and the Extractive Industries; SSRN: 2017; p. 11. Available online: https: / / papers.ssrn.com/sol3/papers.cfm?abstract_id=3244047 (accessed on 1 June 2021).

94. International Bar Association. Achieving Justice and Human Rights in an Era of Climate Disruption-Climate Change Justice and Human Rights Task Force Report; IBA: London, UK, 2014; p. 17. 
95. Kuiper, E.J. Five Years Since the Paris Agreement, Are Banks' 2050 Pledges Enough to Reign in Fossil Fuel Finance? Banktrack, 2020. Available online: https://www.banktrack.org/blog/five_years_since_the_paris_agreement_bank_pledges_are_coming_ thick_and_fast_but_will_they_hit_fossil_fuel_finance (accessed on 8 July 2021).

96. Colman, Z. The New Science Fossil fuel Companies Fear. Politico, 22 August 2019. Available online: https://www.politico.com/ agenda/story/2019/10/22/attribution-science-fossil-fuels-climate-change-001290/ (accessed on 1 June 2021). 